\title{
Modeling the Effect of Climate Change and Economic Growth on food Security Indicators in Ghana
}

\author{
Sampson Twumasi-Ankrah, Wilhemina Adoma Pels, Dennis Kankam Danquah, Doris Arthur
}

\begin{abstract}
Hunger is on the rise in almost all sub-regions of Africa, where the prevalence of undernourishment has reached levels of 22.8 percent in sub-Saharan Africa. Therefore, the purpose of this study is to examine the effect of economic growth and climatic factors on food security in Ghana using different functional forms of regression analysis. Annual secondary data on food security indicators, gross domestic product, $\mathrm{CO}_{2}$, rainfall and temperature spanning from 1999 to 2017 were obtained from the Food and Agricultural Organization (FAO) and World Bank websites. The principal component analysis and regression method were used to reduce the dimensionality of the variable and model the effect of economic growth and climatic factors on food security in Ghana respectively. The dimensions of food availability, stability and utilization were reduced from 5, 6 and 9 variables to 2 variables respectively. However, the dimension of food accessibility was reduced from 3 variables to 1 variable. Food Security Index (FSI) was constructed for each of the food security indicators, and competing models were fitted to the data. It was observed that, GDP has a positive effect on food accessibility, availability, stability and utilization. However, temperature negatively affects food accessibility and stability but a positive effect on food utilization. Rainfall has a negative effect on food stability and $\mathrm{CO} 2$ has a negative effect on food availability, stability and utilization.
\end{abstract}

Keywords: Food Security, Principal Component Analysis, Food Security Index, and Regression

\section{INTRODUCTION}

Food security can be defined as people having both physical and economic access to enough safe and nutritious food that meets their dietary needs and food preferences for an active and healthy life [2]. The components of food security are: availability, accessibility, utilization and stability.

Revised Manuscript Received on June 30, 2020.

* Correspondence Author

Sampson Twumasi-Ankrah*, Department of Statistics and Actuarial Science, Kwame Nkrumah University of Science and Technology, Kumasi, Ghana, PMB UPO. Email: stankrah2017@gmail.com

Wilhemina Adoma Pels, Department of Statistics and Actuarial Science, Kwame Nkrumah University of Science and Technology, Kumasi, Ghana. Email: wilhemina.a.pels@aims-senegal.org

Doris Arthur, Department of Statistics and Actuarial Science, Kwame Nkrumah University of Science and Technology, Kumasi, Ghana. Email: arthur478@gmail.com

Dennis Kankam Danquah, Department of Mathematical Sciences, University of Mines and Technology, Tarkwa, Ghana. Email: nanakankam@gmail.com

(c) The Authors. Published by Blue Eyes Intelligence Engineering and Sciences Publication (BEIESP). This is an open access article under the CC BY-NC-ND license (http://creativecommons.org/licenses/by-nc-nd/4.0/)
Out of the two (2) billion people who suffer from food insecurity, 1.04 billion people (52 percent) are in Asia; Africa is the second with 676 million people (34 percent); and the third is Latin America with 188 million people (9 percent) [11]. In these areas, hunger is on the increase especially in Africa, where the prevalence of undernourishment has reached levels of 22.8 percent in sub-Saharan Africa. Beyond hunger, the degree of food insecurity shows that 1.3 billion people (17.2 percent) of the world population have experienced food insecurity at moderate levels [11]. Therefore, it is desirable to have detailed knowledge about the factors that influences food security.

In literature, factors such as conflict, climate variability and economic slowdowns have been identified to be behind the recent rise in hunger $[8,14,17,2]$. In context, according to [2], African region has high physical sensitivity to climate change which often result in increased average temperatures and rainfall variability and these negatively affect food production and water resources. Thus, in the Sub-Saharan Africa, it is often anticipated that environmental changes would cause extensive yield misfortunes in most rural harvests [20, 24, 28, 6, 9, 19]. Also, agriculture production is a source of food and income, that is the lives of both urban and rural households are greatly affected in terms of food insecurity. Specifically, [16], [7], [13] and [25] have shown that rising gross domestic product (GDP) affects food security positively. Some of the previous studies on the effect of climate change, economic factors on food security in Ghana are discussed: According to [3], crop production in the early 80 's declined drastically in Ghana due to the 1981 - 1983 drought while [23] concluded that variability in rainfall from the 1970 to 2003 significantly influenced root crop production in Ghana. More generally, [13] indicated that irrigated land area has a positive effect on food security. Again, [12], [21], [5] and [22] also showed that climate variability can badly affect food security. Again, authors like [1], [2], [4], [10] and [27] examined the implications of climate change on food security in some parts of Ghana. They concluded that there is negative impact of climate change on food security in Ghana.[18] analyzed the determinants of food availability and access, and the causes of unsustainable food access in Ghana using regression analysis. With only two food indicators, that is food availability and access, it was concluded that, domestic interest rate, exchange rate and oil price have negative effects on food accessibility. 


\section{Modeling the Effect of Climate Change and Economic Growth on food Security Indicators in Ghana}

The study seeks to examine the effect of climate change and economic factors on food security in Ghana.

This study is different from previous studies that have been reviewed in the following ways: (1) we considered all the four components of food security in the analysis; (2) food security index was constructed using principal component analysis; (3) both climate change and economic factors were considered simultaneously in the model building.

\section{MATERIALS AND METHODS}

In this section, we describe the techniques, data source and acquisition that are used in this study.

In this section, we describe the techniques, data source and acquisition that are used in this study.

\section{A. Data source:}

This study aims to assess the impact of climate and economic factors such as Rainfall, $\mathrm{CO}_{2}$, temperature, and GDP respectively on food security indicators: food availability, food accessibility, food utilization, and food stability. This study is based on a yearly secondary data from 1999 to 2017. The data were obtained from the Food and Agriculture Organization and the World Bank websites.

\section{B. Algorithm for the Analysis}

The flow or the procedure for the analysis of this study are indicated below:

1) Check for the percentage of missing values and perform missing values imputation

2) Standardized the variables since they are with different measuring units

3) Perform principal component analysis to reduce the dimensionality of the variables and use the reduced variables to construct index for each food security indicators

4) Fit competing models to the data with a lot of functional forms including interactions and the best model in models with the same functional form in the dependent variable is selected by the $\mathrm{R}^{2}$ adjusted while as the sum of squared error is used to select the best model when the functional form of the dependent variable is not the same.

5) Diagnostic tests are performed on the selected model

\section{Standardization:}

This is a process of putting different variables on the same scale. Mathematically, standardization is given by:

$$
\mathrm{Z}=\frac{\mathrm{X}-\mu}{\sigma}
$$

where $x$ is a random variable, $\mu$ is the mean and $\sigma$ is the standard deviation.

\section{Missing data imputation technique (Kalman smoothing imputation):}

In this study, the Kalman smoothing techniques are used to impute the missing values. This imputation method uses Kalman filters to operate on state-space models of the form

$$
\begin{array}{lc}
y_{\mathrm{t}}=\mathrm{Z} \alpha_{\mathrm{t}}+\varepsilon_{\mathrm{t}} & \varepsilon_{\mathrm{t}} \sim \mathrm{N}(0, \mathrm{H}) \\
\alpha_{\mathrm{t} 1}=\mathrm{T} \alpha_{\mathrm{t}}+\mathbf{n}_{\mathrm{t}} & \mathbf{n}_{\mathrm{t}} \sim \mathrm{N}(0, \mathrm{Q}) \\
\mathbf{a}_{\mathrm{t}} \sim \mathrm{N}\left(\mathrm{a}_{\mathrm{t}}, \mathrm{P}_{\mathrm{t}}\right) &
\end{array}
$$

where $\boldsymbol{y}_{t}=$ observed series (possibly with missing values) and $\boldsymbol{\alpha}_{t}=$ unobserved, the transition equation, $\boldsymbol{\alpha}_{t 1}$ implies the unobserved states evolve over time in a particular way. Kalman filter uses algorithm to find best estimates of $\boldsymbol{\alpha}_{t}$. Kalman Smoothing uses imputeTS package in $\mathrm{R}$ and "na.kalman" to replace the missing values in $\mathrm{R}$.

\section{E. Data Reduction Technique:}

The principal components analysis (PCA) technique was used to reduce the dimensionality of the variables in this study. The notation used for defining PC's follows a criterion used by Joliffe [15]. Given that, $\mathbf{X}=\mathbf{a}$ vector of $\mathbf{p}$ random variables, $\mathbf{a}_{1}=\mathrm{a}$ vector of $\mathbf{p}$ constants, $\mathbf{a}_{1}{ }^{\prime}=$ the transpose of the vector. The first PC is then the linear equation:

$$
a_{1}^{i} x=a_{11} x_{1}+a_{12} x_{2}+\cdots+a_{1 p} x_{p}=\sum_{1=1}^{p} a_{1 j} x_{1}
$$

\section{F. Empirical Models:}

The multiple linear regression model is used in this study to capture the effect of the independent variables (temperature, rainfall, $\mathrm{CO} 2$ emission and GDP) on the dependent variable (food security indicators). The multiple linear regression is of the form:

$$
\mathbf{Y}=\boldsymbol{\beta}_{0}+\boldsymbol{\beta}_{1} \mathbf{x}_{1}+\boldsymbol{\beta}_{2} \mathbf{x}_{2}+\boldsymbol{\beta}_{3} \mathbf{x}_{3}+\boldsymbol{\beta}_{4} \mathrm{x}_{4}+\boldsymbol{\beta}_{1} \mathrm{D}_{1}+\varepsilon
$$

where;

$\mathbf{Y}=$ dependent variable (food accessibility, availability, stability and utilization)

$\beta^{\prime} \mathbf{s}=$ coefficients, $\mathbf{x}^{\prime} \mathbf{s}=$ independent variables (temperature, rainfall, CO2 emission and GDP), D's = interactions between independent variables, and $\varepsilon=$ random error.

\section{G. Criteria in selecting the suitable model among competing models:}

This study consists of 12 competing models with their dependent variables having the same functional form and one (1) model having a different functional form of its dependent variable. Per this, the following criteria is used in selecting the most suitable model.

- If dependent variable of competing models is of the same form, then select the model with the highest Adjusted R-Square.

- If the model with the highest Adjusted R-Square does not have a higher number of significant variables, then select the model with the next higher Adjusted R-Square but with the highest number of significant variables.

- Afterwards, compare the sum of square errors of the selected model and that of the model with different functional form.

\section{H. Model Assumptions:}

Regression analysis is a parametric test which assumes certain characteristics of the data. Some of the assumptions include autocorrelation and heteroscedasticity. 
Heteroscedasticity Test: Breusch-Pagan Test was used to test the presence of heteroscedasticity with null hypothesis that error variances are equal at a significance value of 0.05 . The test statistic is given as:

$$
\mathbf{L M}=\mathbf{n R}^{2} \quad(\mathrm{k} \text { degree of freedom })
$$

where $\boldsymbol{n}$ is the sample size, $\boldsymbol{R}^{2}$ is the coefficient of

determination of the regression of squared residuals from the original regression and $\boldsymbol{k}$ is the number of independent

variables.

Autocorrelation Test: The Durbin Watson Test was used to measure autocorrelation in the residual from the regression model with a null hypothesis that there is no autocorrelation between the errors at 0.05 significance level. The test has a test statistic given by

$$
\mathrm{DW}=\frac{\sum_{\mathrm{t}=2}^{\mathrm{T}}\left(\mathrm{e}_{\mathrm{t}}-\mathrm{e}_{\mathrm{t}-1}\right)^{2}}{\sum_{\mathrm{T}=1}^{\mathrm{T}} \mathrm{e}_{\mathrm{t}}^{2}}
$$

where the $\mathbf{e}_{\mathbf{t}}$ s $\mathbf{s}$ are residuals from an ordinary least square regression.

\section{RESULTS AND DISCUSSION}

In this section, two major objectives are carried out. Firstly, the principal component analysis was used to construct an index for food security by reducing the dimensionality of the variables in the four food security indicators. Secondly, twelve (12) competing linear models with different functional forms were compared by the use of their adjusted R-square and their sum of square errors in order to select a suitable model that best show the impact of climatic and economic factors on the four food security indicators.

\section{A. Preliminary Analysis:}

The sample size for all variables was 18 . However, some of the variables had missing values in them. Percentage of children under 5 years affected by wasting (PCUAW), Percentage of children under 5 years of age who are stunted (PCUAS), Percentage of children under 5 years of age who are overweight (PCAO) and Prevalence of exclusive breastfeeding among infants $0-5$ months of age (PEBAI) recorded the highest number of missing value with a rate of 77.78\% whiles Temperature, rainfall and GDP recorded no missing value (see Table I).

\section{B. Imputation Method and Standardization of Data:}

According to [26], the Kalman smoothing method of imputation is appropriate for such dataset. Thus, the Kalman smoothing method was used to impute missing values. Due to fact that almost all the variables are not of the same measure of units, the data was then standardized for all units to have one measure.

\section{Constructing Food Security Index}

Reducing the Dimensionality of Food Security Indicators: This simplifies the complexity in high-dimensional data while retaining trends and patterns and transforming the data into fewer dimensions by following laid down procedures:

1) Sample Adequacy and Correlation Matrix Identity Test: Kaiser-Meyer-Olkin (KMO) test was used to test the sample adequacy of the data. Food Utilization, Food Availability and Food Stability Samples are adequate since they showed KMO values greater than 0.500 whiles Food Accessibility sample is inadequate with a KMO value of 0.39 (see Table II).

2) The Bartlett's test of sphericity was also used to test the null hypothesis whether the original correlation matrix is equal to an identity matrix at a significance value of 0.05 . The Bartlett's test of sphericity for all indicators showed a p-value of $<0.0001$.

Thereby, showing that none of the variables is an identity matrix (see Table II).

Table-II: KMO and Bartlett's Test for sphericity

\begin{tabular}{|c|c|c|}
\hline Indicators & $\begin{array}{c}\text { KMO } \\
\text { test } \\
\text { statistics }\end{array}$ & $\begin{array}{c}\text { Bartlett's Test } \\
\text { for sphericity } \\
\text { (P-Value) }\end{array}$ \\
\hline Food Utilization & 0.75 & $<0.0001$ \\
\hline $\begin{array}{c}\text { Food } \\
\text { Accessibility }\end{array}$ & 0.39 & $<0.0001$ \\
\hline $\begin{array}{c}\text { Food } \\
\text { Availability }\end{array}$ & 0.6 & $<0.0001$ \\
\hline Food Stability & 0.56 & $<0.0001$ \\
\hline
\end{tabular}

Determining the Number of Components to Extract:

From Table III, components 1 and 2 with eigenvalues greater than 1 and variation explained of 52\% and 48\% respectively were retained and extracted for Food Availability.

In component 1 and component 2, ASPAO and APS had the highest factor loadings in their respective principal components. Hence, these two were utilized in the calculation of weight for food security index with regards to food availability (Table III).

Table- III: Food Availability eigenvalues and Rotated Component Matrix

\begin{tabular}{|c|c|c|c|}
\hline Components & Eigenvalues & Variance & $\%$ Variance \\
\hline 1 & 3.73889711 & 1.39054766 & 0.7477794 \\
\hline 2 & 1.08366458 & 1.0202902 & 0.2167329 \\
\hline 3 & 0.13621223 & 0.60751083 & 0.0272425 \\
\hline 4 & 0.03231097 & 0.42397231 & 0.0064622 \\
\hline 5 & 0.00891511 & 0.30727815 & 0.001783 \\
\hline
\end{tabular}




\begin{tabular}{|c|c|c|}
\hline $\begin{array}{c}\text { Variables } \\
\left(V_{i}\right)\end{array}$ & $\begin{array}{c}\text { Component } \\
1\left(C_{i}\right)\end{array}$ & $\begin{array}{c}\text { Component } \\
2\left(C_{i}\right)\end{array}$ \\
\hline ADESA & 0.71934 & 0.67691 \\
AVOEP & 0.83492 & 0.4714 \\
& & \\
SDESDCRI & -0.56295 & -0.8039 \\
APS & 0.00832 & $\mathbf{0 . 9 9 7 8 1}$ \\
ASPAO & $\mathbf{0 . 9 8 4 1}$ & -0.01699 \\
\hline Total & & \\
(Absolute & & \\
values) & 3.10963 & 2.96701 \\
Proportion & & \\
Variance & 0.49999 & 0.46452 \\
Proportion & & \\
Explained & $52 \%$ & $48 \%$ \\
\hline
\end{tabular}

From Table IV, two components (1 and 2) are with eigenvalues greater than 1 were retained for Food Stability. Their proportion of variation explained are $71 \%$ and $29 \%$ respectively. PALEI from component 1 and PSAVT from component 2 were extracted for the index of food security in regards to food stability since the two had the highest factor loadings in each case (Table IV).

Table- IV: Food Stability eigenvalues and Rotated Component Matrix

\begin{tabular}{|c|c|c|c|}
\hline Components & Eigenvalues & Variance & \% Variance \\
\hline 1 & 3.39013866 & 1.35692037 & 0.5650231 \\
\hline 2 & 1.11144607 & 1.02676745 & 0.185241 \\
\hline 3 & 0.98406306 & 0.99599172 & 0.1640105 \\
\hline 4 & 0.33839261 & 0.76270258 & 0.0563988 \\
\hline 5 & 0.10589933 & 0.57045751 & 0.0176499 \\
\hline 6 & 0.07006027 & 0.51447936 & 0.0116767 \\
\hline
\end{tabular}

\begin{tabular}{|c|c|c|}
\hline $\begin{array}{c}\text { Variables } \\
\left(V_{i}\right)\end{array}$ & $\begin{array}{c}\text { Component } \\
1\left(C_{i}\right)\end{array}$ & $\begin{array}{c}\text { Component } \\
2\left(C_{i}\right)\end{array}$ \\
\hline CIDR & -0.8808 & -0.03867 \\
PALEI & $\mathbf{- 0 . 9 3 2 8 6}$ & -0.02604 \\
VEITME & 0.07375 & 0.73412 \\
PSAVT & 0.15032 & $\mathbf{0 . 8 1 1 2 3}$ \\
PCEPV & 0.89053 & 0.23393 \\
PCFSV & 0.85508 & 0.22219 \\
\hline Total & & \\
(Absolute & & \\
values) & 3.78334 & 2.06618 \\
Proportio & & \\
n Variance & 0.53305 & 0.21722 \\
\hline Proportio & & \\
$\mathrm{n}$ & & \\
Explained & $71 \%$ & $29 \%$ \\
\hline
\end{tabular}

From Table V, components 1 and 2 also showed eigenvalues greater than 1 while component 3 to 9 showed eigenvalues less than 1 pertaining to Food Utilization. The proportion of variation being explained by component 1 and component 2 were $77 \%$ and $23 \%$ respectively. Component 1 and 2 are extracted. From the rotated component matrix, POAP and PEBAI were the two variables chosen to represent Food Utilization cases in Ghana since they had the highest factor loadings (Table V).

Table-V: Food Utilization eigenvalues and Rotated Component Matrix

\begin{tabular}{|c|c|c|c|}
\hline Components & Eigenvalues & Variance & $\begin{array}{c}\% \\
\text { Variance }\end{array}$ \\
\hline 1 & 7.317545 & $\begin{array}{c}1.644717 \\
6\end{array}$ & $\begin{array}{c}0.813060 \\
5\end{array}$ \\
\hline 2 & 1.336994 & $\begin{array}{c}1.075306 \\
7\end{array}$ & $\begin{array}{c}0.148554 \\
9\end{array}$ \\
\hline 3 & 0.245981 & $\begin{array}{c}0.704247 \\
6\end{array}$ & $\begin{array}{c}0.027331 \\
2\end{array}$ \\
\hline 4 & 0.085992 & $\begin{array}{c}0.541519 \\
4\end{array}$ & $\begin{array}{c}0.009554 \\
6\end{array}$ \\
\hline 5 & 0.00735 & 0.29279 & $\begin{array}{c}0.000816 \\
6\end{array}$ \\
\hline 6 & 0.004933 & $\begin{array}{c}0.265017 \\
2\end{array}$ & $\begin{array}{c}0.000548 \\
1\end{array}$ \\
\hline 7 & 0.000881 & $\begin{array}{c}0.172277 \\
1\end{array}$ & $9.787 \mathrm{E}-05$ \\
\hline 8 & 0.000237 & $\begin{array}{c}0.124017 \\
4\end{array}$ & $2.628 \mathrm{E}-05$ \\
\hline 9 & 0.000089 & $\begin{array}{c}0.097254 \\
6\end{array}$ & $9.94 \mathrm{E}-06$ \\
\hline
\end{tabular}

\begin{tabular}{|c|c|c|}
\hline Variables $\left(V_{i}\right)$ & $\begin{array}{c}\text { Component } \\
1\left(C_{i}\right)\end{array}$ & $\begin{array}{c}\text { Component } \\
2\left(C_{i}\right)\end{array}$ \\
\hline & & \\
PPSMDWS & 0.98372 & -0.16334 \\
PPLBWS & 0.98065 & -0.15695 \\
PPLBSS & 0.98183 & -0.15113 \\
PCUAW & -0.83596 & 0.49298 \\
PCUAS & -0.97176 & 0.22318 \\
PCAO & -0.52077 & 0.80248 \\
POAP & $\mathbf{0 . 9 8 4 8 7}$ & -0.15655 \\
& -0.93544 & 0.22794 \\
PAAWOPA & -0.0027 & $\mathbf{0 . 9 5 6 2 2}$ \\
PEBAI & & \\
\hline & & \\
Total (Absolute & 7.1977 & 3.33077 \\
values) & & \\
Proportion & 0.73919 & 0.22242 \\
Variance & & \\
Proportion & & $23 \%$ \\
Explained & $77 \%$ & \\
\hline
\end{tabular}


Component 1 explained about 83\% variation in Food Accessibility with an eigenvalue greater than 1 . Therefore, component 1 was extracted. Using the highest factor loadings for the construction of the index from the rotated component matrix, POU exhibited the highest value. Hence, it was used (Table VI).

Table-VI:. Food Accessibility eigenvalues and Rotated Component Matrix

\begin{tabular}{|c|c|c|c|}
\hline Component & Eigenvalues & Variance & \% Variance \\
\hline 1 & 2.48470564 & 1.255505834 & 0.8282352 \\
\hline 2 & 0.51162201 & 0.845740859 & 0.1705407 \\
\hline 3 & 0.00367235 & 0.246170508 & 0.00122412 \\
\hline Variables $\left(V_{i}\right)$ & \multicolumn{3}{|c|}{ Component $1\left(C_{i}\right)$} \\
\hline GDPPC & \multicolumn{3}{|c|}{-0.80123} \\
NOPU & & 0.92981 \\
POU & & 0.98903 \\
\hline $\begin{array}{c}\text { Proportion } \\
\text { Variance } \\
\text { Total } \\
\text { (Absolute } \\
\text { values) }\end{array}$ & 0.82824 \\
\hline
\end{tabular}

Food Security Index: In getting the index for the food security indicators, a weight is computed for all the components retained. The weight is formulated as

$$
W V_{\mathrm{i}}=\frac{\mathrm{C}_{\mathrm{i}}}{\sum_{\mathrm{i}=1}^{\mathrm{n}}\left|\mathrm{C}_{\mathrm{i}}\right|}
$$

where $\mathrm{C}_{\mathrm{i}}$ is the highest factor loading for $\mathrm{i}^{\text {th }}$ component retained on a particular food indicator, $\mathrm{WV}_{\mathrm{i}}$ is the weight of the $i^{\text {th }}$ variable with the highest factor loadings and $n$ is the number of factor loadings with regards to the particular variable.

Weights of the variables extracted were normalized to get single dependent variable for the regression analysis of food security indicators. Normalized weight is given by:

$\mathrm{N}_{\mathrm{W}}=\frac{\mathrm{W} \mathrm{v}_{\mathrm{i}}}{\sum_{\mathrm{i}}^{\mathrm{n}}\left|\mathrm{W} \mathrm{v}_{\mathrm{i}}\right|}$,

where $\mathrm{WV}_{\mathrm{i}}$ is the weight of the $\mathrm{i}^{\text {th }}$ variable.

Food Security Index (FSI) to represent Ghana's food security cases was created using the selected variables from the Retained Component Matrix of the PCA and their respective weights (Table VII).

Table- VII: Summary of weight for the retained variable

\begin{tabular}{|c|c|c|}
\hline Retained Variable & Weight $\left(W V_{i}\right)$ & $\begin{array}{c}\text { Normalized Weight } \\
\left(N_{w}\right)\end{array}$ \\
\hline POU & 0.36360461 & 0.36360461 \\
\hline
\end{tabular}

D. Effect of climate and economic factors on food security dicators:

Regression models were fitted to the dataset where each sector of the food security component is the dependent variable and temperature, rainfall, $\mathrm{CO}_{2}$ emission and GDP are the independent variables. Thirteen different functional forms of regression model including linear, log-linear, log-log, lin-log, quadratic, cubic and interaction models were fitted to the dataset. The $\mathrm{R}^{2}$ adjusted and the sum of squared error were used to select the best model at each stage of the food security indicator component. The reduced models for the food security indicators for each component are giving in Table VIII.

Food Accessibility

It is observed that, GDP (which is a proxy of economic growth) significantly has a positive effect on food accessibility. Hence, a unit change in economic growth increases food accessibility by 0.26287 holding all other factors constant; and this model explains $72.62 \%$ of the total variation in food accessibility.

\section{Food Availability}

Again, the result indicates that $\mathrm{CO}_{2}$ emissions, GDP, the interactions between GDP and temperature; and that of GDP and $\mathrm{CO}_{2}$ emissions have a significant effect on food availability. 


\section{Modeling the Effect of Climate Change and Economic Growth on food Security Indicators in Ghana}

Specifically, the two interactions terms, that is GDP and temperature; and GDP and $\mathrm{CO}_{2}$ emissions both have a negative effect on the Average Protein Supply and that of the average supply of protein of animal origin.

And $\mathrm{CO}_{2}$ emission decreases both average protein supply and average supply of protein of animal origin by 0.1329 holding all other factors constant. However, GDP positively affects food availability by 0.8034 .

\section{Food Stability}

Furthermore, GDP, interaction terms of temperature and rainfall; rainfall and $\mathrm{CO}_{2}$ emission; temperature and $\mathrm{CO}_{2}$ emission; GDP and Temperature; and Temperature and Rainfall and $\mathrm{CO}_{2}$ emission increases food stability by 0.669 , $0.679,0.674,0.5766$ and 1.4155 respectively. However, temperature, rainfall, $\mathrm{CO}_{2}$ emission, interaction of GDP and Rainfall; interaction of GDP and temperature; interaction of temperature and rainfall and $\mathrm{CO}_{2}$ emission decreases food stability by $0.245,0.247,0.769,0.78,0.515$ and 1.11 respectively holding all other factors constant.

\section{Food Utilization}

In the case of food utilization, GDP, Temperature, rainfall and $\mathrm{CO}_{2}$ emission; temperature and $\mathrm{CO}_{2}$ emission increase food utilization by $0.243,0.538,0.368,1.66$ respectively. However, $\mathrm{CO}_{2}$ emission, GDP and Rainfall, GDP and Temperature, GDP and $\mathrm{CO}_{2}$; GDP and temperature and $\mathrm{CO}_{2}$ emission; and GDP and rainfall and $\mathrm{CO}_{2}$ emission decrease food utilization by $0.471,0.461,1.491,0.163,0.527$ and 0.229 respectively holding all other factors constant.

Heteroscedasticity: The Breusch-Pagan Test was used to test for the presence of constant variance in the selected reduced model, with null hypothesis: No Heteroscedasticity present or variance of error is constant. For all the regression models for the food security components, we fail to reject the null hypothesis at the significance value of 0.05 and conclude that there exists constant variance in the selected models for all the indicators (Table IX).

Table- IX: Breusch-Pagan Test for Heteroscedasticity

\begin{tabular}{|c|c|c|c|c|}
\hline \multirow{2}{*}{ Variable } & \multicolumn{2}{|c|}{$\begin{array}{r}\text { Heteroscedasticity } \\
\text { (BP) }\end{array}$} & \multicolumn{2}{|c|}{$\begin{array}{r}\text { Autocorrelation } \\
\text { (DW) }\end{array}$} \\
\cline { 2 - 5 } & $\begin{array}{c}\text { Test } \\
\text { Statistics }\end{array}$ & p-value & $\begin{array}{c}\text { Test } \\
\text { Statistics }\end{array}$ & p-value \\
\hline $\begin{array}{c}\text { Food } \\
\text { Accessibility }\end{array}$ & 5.2971 & 0.1513 & 0.85489 & 0.05681 \\
\hline $\begin{array}{c}\text { Food } \\
\text { Availability }\end{array}$ & 4.864 & 0.4327 & 1.4281 & 0.149 \\
\hline $\begin{array}{c}\text { Food } \\
\text { Stability }\end{array}$ & 11.101 & 0.4348 & 2.5728 & 0.793 \\
\hline $\begin{array}{c}\text { Food } \\
\text { Utilization }\end{array}$ & 11.568 & 0.3969 & 2.2839 & 0.286 \\
\hline
\end{tabular}

Autocorrelation: The Durbin-Watson Test aids in testing for the presence of autocorrelation between errors in the selected reduced model, with null hypothesis: Residuals are uncorrelated (errors are independent). From Table IX, there is no autocorrelation among the residuals for all the food security components.

\section{CONCLUSION}

Food Availability, Stability and Utilization dimensions were reduced from 5, 6 and 9 variables to 2 variables respectively. Food Accessibility dimension was reduced from 3 variables to 1 variable. The reduced variables for Food Availability, Stability, Utilization, Accessibility are Average Protein Supply and Average Supply of Protein of Animal Origin; Percent of Arable Land Equipped for Irrigation and Political Stability and Absence of Violence/Terrorism; Prevalence of obesity in the adult population and Prevalence of exclusive breastfeeding among infants 0-5 months of age; Prevalence of Undernourishment respectively. The Food Security Index (FSI) created is the "best" representation of food security cases in Ghana and an increase or decrease in the variables will directly affect the respective food security indicator and the level of food security cases in Ghana. It was observed that, GDP has a positive effect on food accessibility, availability, stability and utilization. However, temperature negatively affect food accessibility and stability but a positive effect on food utilization. Rainfall has a negative effect on food stability and CO2 has a negative effect on food availability, stability and utilization.

\section{REFERENCES}

1. Akudugu, M. A., Dittoh, S., \& Mahama, E. S. 2012. The implications of climate change on food security and rural livelihoods: Experiences from Northern Ghana. Journal of Environment and Earth Science, 2(3), 21-29.

2. Antwi, A. 2013. Climate Change and Food Security: An Overview About the Issue. Friedrich Ebert Foundation, pp. 13.

3. Asante, A. 2004. Assessment of food import and food aid against support for agricultural development, the case of Ghana. Draft report for FAO Regional Office, 10.

4. Atitsogbey, Patience 2016. The impact of climate change on food and nutrition security in the Bongo District of the upper east region of Ghana (Doctoral dissertation, University of Ghana)

5. Badolo, F., \& Kinda, S. 2014. Climatic variability and food security in developing countries. Etudes et Documents, (05).

6. Barron, J., Kemp-Benedict, E., Morris, J., de Bruin, A., Wang, G., \& Fencl, A. 2015. Mapping the potential success of agricultural water management interventions for smallholders: Where are the best opportunities?. Water Resources and Rural Development, 6, 24-49.

7. Carter, K. N., Lanumata, T., Kruse, K., \& Gorton, D. 2010. What are the determinants of food insecurity in New Zealand and does this differ for males and females?. Australian and New Zealand journal of public health, 34(6), 602-608.

8. Christensen, J. H., Hewitson, B., Busuioc, A., Chen, A. G., \& Gao, X. 2007. X., Held, I., Jones, R., Kolli, RK, Kwon, W. T., Laprise, R., Magana Rueda, V., Mearns, L., Menendez, CG, Raisanen, J., Rinke, A., Sarr, A. and Whetton, $P$.

9. Desai, B., Maskrey, A., Peduzzi, P., De Bono, A., \& Herold, C. 2015. Making development sustainable: the future of disaster risk management, global assessment report on disaster risk reduction.

10. Dinko, H. D. 2017. Climate change and changing food security risk in Ghana. African Journal of Agriculture and Food Security, 5(3), 186-192. 
11. FAO, IFAD, UNICEF, WFP and WHO. 2019. The State of Food Security and Nutrition in the World 2019. Safeguarding against economic slowdowns and downturns. Rome, FAO. Licence: CC BY-NC-SA 3.0 IGO.

12. Gregory, P. J., Ingram, J. S., \& Brklacich, M. 2005. Climate change and food security. Philosophical Transactions of the Royal Society B: Biological Sciences, 360(1463), 2139-2148.

13. Herath, H. M. S. P. 2014. Impacts of Regional trade agreements (RTAS) on food security: A case of ASEAN Free trade agreement. Impacts of Regional Trade Agreements (RTAs) on Food Security: A Case of ASEAN Free Trade Agreement (March 1, 2014).

14. Ingram, L. J., Stahl, P. D., Schuman, G. E., Buyer, J. S., Vance, G. F., Ganjegunte, G. K., ... \& Derner, J. D. 2008. Grazing impacts on soil carbon and microbial communities in a mixed-grass ecosystem. Soil Science Society of America Journal, 72(4), 939-948.

15. Jolliffe, I. T., \& Cadima, J. 2016. Principal component analysis: a review and recent developments. Philosophical Transactions of the Royal Society A: Mathematical, Physical and Engineering Sciences, 374(2065), 20150202.

16. Kargbo, J. M. 2000. Impacts of monetary and macroeconomic factors on food prices in eastern and southern Africa. Applied Economics, 32(11), 1373-1389.

17. Keane, J., Page, S., Kergna, A., \& Kennan, J. 2009. Climate change and developing country agriculture: An overview of expected impacts, adaptation and mitigation challenges, and funding requirements. Issue Brief, 2, 1-49.

18. Kofi, A. P 2014. Determinants of food availability and access in Ghana: what can we learn beyond the regression results? Studies in Agricultural Economics, 116(3):153-164.

19. Mârza, B., Angelescu, C., \& Tindeche, C. 2015. Agricultural insurances and food security. The new climate change challenges. Procedia Economics and Finance, 27, 594-599.

20. Molle, F., \& Mollinga, P. 2003. Water poverty indicators: conceptual problems and policy issues. Water policy, 5(5-6), 529-544.

21. Misselhorn, A. A. 2005. What drives food insecurity in southern Africa? A meta-analysis of household economy studies. Global environmental change, 15(1), 33-43.

22. Rutten, M., Van Dijk, M., Van Rooij, W., \& Hilderink, H. 2014. Land use dynamics, climate change, and food security in Vietnam: a global-to-local modeling approach. World Development, 59, 29-46.

23. Sagoe, R. 2006. Climate change and root crop production in Ghana. A report prepared for Environmental Protection Agency (EPA), Accra-Ghana February.

24. Schlenker, W., \& Lobell, D. B. 2010. Robust negative impacts of climate change on African agriculture. Environmental Research Letters, 5(1), 014010.

25. Tadasse, G., Algieri, B., Kalkuhl, M., \& Von Braun, J. 2016. Drivers and triggers of international food price spikes and volatility. In Food price volatility and its implications for food security and policy (pp. 59-82). Springer, Cham.

26. Twumasi-Ankrah, S., Odoi, B., Pels, W. A., \& Gyamfi, E. H. 2019. Efficiency of imputation techniques in univariate Time Series.

27. Wood, A. L., Ansah, P., Rivers III, L., \& Ligmann-Zielinska, A. 2019. Examining climate change and food security in Ghana through an intersectional framework. The Journal of Peasant Studies, 1-20.

28. Zorom, M., Barbier, B., Mertz, O., \& Servat, E. 2013. Diversification and adaptation strategies to climate variability: A farm typology for the Sahel. Agricultural Systems, 116, 7-15. 
Table I. Summary of number of missing values in the data

\begin{tabular}{|c|c|}
\hline Variable & Missing (\%) \\
\hline \multicolumn{2}{|l|}{ Food Accessibility } \\
\hline Gross domestic product per capita dissemination (GDPPC) & $1(5.56)$ \\
\hline Prevalence of undernourishment (POU) & $2(11.11)$ \\
\hline Number of people undernourished (NOPU) & $2(11.11)$ \\
\hline \multicolumn{2}{|l|}{ Food Availability } \\
\hline Average dietary energy supply adequacy (ADESA) & $2(11.11)$ \\
\hline Average value of food production (AVOEP) & $3(16.67)$ \\
\hline Share of dietary energy supply derived from cereals, roots and tubers (SDESDCRT) & $6(33.33)$ \\
\hline Average protein supply (APS) & $6(33.33)$ \\
\hline Average supply of protein of animal origin (ASPAO) & $6(33.33)$ \\
\hline \multicolumn{2}{|l|}{ Food Stability } \\
\hline Cereal import dependency ratio (CIDR) & $6(33.33)$ \\
\hline Percent of arable land equipped for irrigation (PALEI) & $4(22.22)$ \\
\hline Value of food imports in total merchandise exports (VFITME) & $6(33.33)$ \\
\hline Political stability and absence of violence/terrorism (PSAVT) & $3(16.67)$ \\
\hline Per capita food production variability (PCFPV) & $2(11.11)$ \\
\hline Per capita food supply variability (PCFSV) & $5(27.78)$ \\
\hline \multicolumn{2}{|l|}{ Food Utilization } \\
\hline Percentage of population using safely managed drinking water services (PPSMDWS) & $3(16.67)$ \\
\hline Percentage of population using at least basic drinking water services (PPLBWS) & $3(16.67)$ \\
\hline Percentage of population using at least basic sanitation services (PPLBSS) & $3(16.67)$ \\
\hline Percentage of children under 5 years affected by wasting (PCUAW) & $14(77.78)$ \\
\hline Percentage of children under 5 years of age who are stunted (PCUAS) & $14(77.78)$ \\
\hline Percentage of children under 5 years of age who are overweight (PCAO) & $14(77.78)$ \\
\hline Prevalence of obesity in the adult population (POAP) & $2(11.11)$ \\
\hline Prevalence of anemia among women of reproductive age (PAAWOPA) & $2(11.11)$ \\
\hline Prevalence of exclusive breastfeeding among infants $0-5$ months of age (PEBAI) & $14(77.78)$ \\
\hline \multicolumn{2}{|l|}{ Economic and climatic factors } \\
\hline $\mathrm{CO}_{2}$ Emissions & $3(16.67)$ \\
\hline Rainfall & $0(0.0)$ \\
\hline Temperature & $0(0.0)$ \\
\hline GDP & $0(0.0)$ \\
\hline
\end{tabular}


Table XIII- Reduced model for Food security indicators

\begin{tabular}{|c|c|c|c|c|}
\hline & Food Accessibility & Food Availability & Food Stability & Food Utilization \\
\hline Variable & Estimates (s.e) & Estimates (s.e) & Estimates (s.e) & Estimates (s.e) \\
\hline Intercept & $-0.01215(0.04424)$ & $0.12972(0.03754)^{*}$ & $0.16805(0.04997)^{*}$ & $-0.01164(-0.05917)$ \\
\hline GDP & $0.26287(0.04600)^{*}$ & $0.8034(0.05444)^{*}$ & $0.66914(0.23545)^{*}$ & $0.24278(0.11594) *$ \\
\hline Temp & $-0.08837(0.04669)^{*}$ & $0.01905(0.02019)$ & $-0.24503(0.07187)^{*}$ & $0.53749(0.18057) *$ \\
\hline Rain & & & $-0.24683(0.10773)^{*}$ & $-0.04437(-0.05655)$ \\
\hline $\mathrm{CO}_{2}$.emissions & & $-0.13290(0.06184)^{*}$ & $-0.76862(0.28527) *$ & $-0.47095(0.17281)^{*}$ \\
\hline GDP:Rain & & & $-0.78143(0.22222)^{*}$ & $-0.46161(0.15924) *$ \\
\hline Temp:Rain & & & $0.67921(0.23887)^{*}$ & \\
\hline Rain: $\mathrm{CO}_{2}$.emissions & & & $0.67407(0.18981)^{*}$ & $0.3633(0.14298)^{*}$ \\
\hline Temp: $\mathrm{CO}_{2}$.emissions & & & $0.57659(0.24750)^{*}$ & $1.66056(0.40410)^{*}$ \\
\hline GDP:Temp & $0.08747(0.05191)$ & $-0.06379(0.02121)^{*}$ & $-0.51470(0.16860)^{*}$ & $-1.4909(0.34994)^{*}$ \\
\hline GDP: $\mathrm{CO}_{2}$.emissions & & $-0.14358(0.03892)^{*}$ & & $-0.16299(0.06757)^{*}$ \\
\hline $\begin{array}{c}\text { Temp:Rain: } \mathrm{CO}_{2} \\
\text { emissions }\end{array}$ & & & $-1.11038(0.42469)^{*}$ & \\
\hline $\begin{array}{l}\text { GDP:Temp: } \mathrm{CO}_{2} \\
\text { emissions }\end{array}$ & & & & $-0.52675(0.16540)^{*}$ \\
\hline $\begin{array}{c}\text { GDP:Rain: } \\
\mathrm{CO}_{2} \text {.emissions }\end{array}$ & & & & $-0.22973(0.07412)^{*}$ \\
\hline GDP:Temp:Rain & & & $1.41553(0.54259)^{*}$ & \\
\hline SSE & 0.1903 & 0.07742 & 0.1036 & 0.1024 \\
\hline F-Statistic & 16.91 & 29.53 & 7.951 & 5.106 \\
\hline P-value & 0.00004454 & 0.00000116 & 0.005626 & 0.02007 \\
\hline Adjusted R-square & 0.7262 & 0.888 & 0.8094 & 0.715 \\
\hline
\end{tabular}

